\title{
Diabetes-Induced Damages in Rat Kidney and Brain and Protective Effects of Natural Antioxidants*
}

\author{
Najla Hfaiedh ${ }^{1 \#}$, Sakria Mbarki ${ }^{1}$, Hichem Alimi ${ }^{2}$, Jean Claude Murat ${ }^{3}$, Abdelfattah Elfeki ${ }^{1}$ \\ ${ }^{1}$ Laboratoire d'Ecophysiologie Animale, Faculté des Sciences, Sfax, Tunisie; ${ }^{2}$ Laboratoire de Physiologie Intégrée, Faculté des \\ Science, Bizerte, Tunisie; ${ }^{3}$ Laboratoire de Biologie Cellulaire, Faculté de Médecine, Toulouse, France. \\ Email: "najlaharrathi@yahoo.fr
}

Received January $25^{\text {th }}, 2013$; revised March $12^{\text {th }}, 2013$; accepted March $20^{\text {th }}, 2013$

Copyright (C) 2013 Najla Hfaiedh et al. This is an open access article distributed under the Creative Commons Attribution License, which permits unrestricted use, distribution, and reproduction in any medium, provided the original work is properly cited.

\begin{abstract}
Context: In case of diabetes, persistent and chronic hyperglycaemia may generate free radicals and reactive oxygen species (ROS), which trigger an oxidative stress. Garlic (Allium sativum) is a rich source of bioactive compounds and is used in folk medicine for the treatment of various diseases, including diabetes. Besides, $\alpha$-tocopherol and magnesium have been shown to possess antioxidative properties. Objective: Protective effects of either a garlic aqueous extract or an association of $\alpha$-tocopherol and magnesium association upon oxidative stress and dysfunctions in kidney and brain of alloxan-diabetic rats were investigated. Results: Both garlic extract and the combination of $\alpha$-tocopherol and magnesium were found to normalize many parameters which were shifted to pathological values as a consequence of the alloxan-induced diabetes: plasma creatinine and urea levels were decreased, protein leakage in urine was reduced and cortisol level was brought back to control value. In addition, superoxide dismutase (SOD), catalase (CAT) and glutathione peroxidase (GPX) activities, which were lowered in kidney and brain of diabetic animals, were restored by both treatments and, consequently, level of lipids peroxidation was reduced in these organs, as compared to diabetic animals. Conclusion: Both garlic extract and $\alpha$-tocopherol + magnesium association display beneficial effects upon nephropathy and oxidative stress in alloxan-diabetic rats. The protective effect of garlic is mainly attributed to antioxidant properties and the presence of phenolic acids and flavonoids.
\end{abstract}

Keywords: Oxidative Stress; Antioxidants; Hyperglycemia and Rat

\section{Introduction}

Diabetes mellitus is a chronic disease which cannot be completely cured and may develop complications if not properly regulated. Diabetes is primarily characterized by a hyperglycaemia which results from lack of insulin or a weak response of tissues to this hormone. It is associated with long-term complications affecting the eyes, kidneys, cardiovascular system and nervous system [1-5]. The persistent and chronic hyperglycaemia generates free radicals and reactive oxygen species (ROS) which trigger an oxidative stress. The overproduction of free radicals and ROS results in: 1) enhanced lipid peroxidation; 2) damages to DNA and protein degradation [6]; and 3) exhaustion of the antioxidative defense systems [7]. Many functional and structural disorders, related to diabetes, were observed in the central and peripheral nervous sys-

\footnotetext{
${ }^{*}$ Conflict of interest: The authors have declared that there is no conflict of interest.

${ }^{\#}$ Corresponding author.
}

tems [8]. Baydas et al. [9] reported that diabetes produces oxidative damage in many regions of rat brain including the hippocampus. Besides, the increased level of plasma cortisol frequently observed in diabetic patients or animals led to the suggestion that the control of diabetes is influenced by the adrenocortical function [10] and that there might be a correlation between stress, plasma cortisol level and diabetes.

Some substances are known to exert some anti-diabetic effect by stimulating pancreatic beta-cells to release insulin or by restoring peripheral sensitivity to insulin [11]. It is reported that about 800 plants may possess such anti-diabetic potential [12].

Garlic is well known for its characteristic resistance to biotic and abiotic environmental stresses. In addition, garlic is stated to possess many therapeutic benefits. Garlic's strong odor is largely due to sulphur-containing compounds (e.g., S-allylcysteine sulfoxide), which are believed to account for most of its medicinal properties 
[13]. Active compounds in garlic were shown to exhibit anticoagulant (anti-thrombotic) [14-16], antioxidant [17, 18], hypocholesterolemic [19], hypoglycaemic [5,18,20], antibacterial, antifungal [21], anticarcinogenic [22] as well as hypotensive properties [23].

Raw garlic was found to alleviate renal damages caused by streptozotocin-induced diabetes in rats [5]. A garlic aqueous extract was reported to prevent atrophic changes in the frontal brain and to improve learning abilities and memory retention in senescence-accelerated mouse [24]. The same author reported that allixin, a component of garlic was found to promote the survival of neurons derived from various regions of the brain and to increase the number of branching points per axon in hippocampus [25]. The antioxidant actions of garlic and its constituents were confirmed by their ability to scavenge reactive oxygen species (ROS), to inhibit lipid peroxidation and lipoproteins oxidation and to enhance efficiency of endogenous antioxidant systems [26].

$\alpha$-Tocopherol (also known as vitamin E), located in cell organelles such as mitochondria, microsomes and chloroplasts, is known to neutralize free radicals, to remove the superoxide anions generated by the reducing enzymes and to prevent the chain reactions which cause oxidative damages $[27,28]$. One prospective epidemiological study indicated that high $\alpha$-tocopherol levels in serum were associated to decreased risks of diabetes mellitus [29]. Consequently, $\alpha$-tocopherol is widely used as adjuvant in the treatment of diabetic patients [30]. Other studies have demonstrated beneficial effects of oral $\mathrm{Mg}$ supplementation to maintain glucose homeostasis and to enhance insulin action [31,32].

Hypomagnesemia, commonly due to insufficient magnesium intake/or increased magnesium loss [33] has been associated with the development of type 2 diabetes [34], high blood pressure [35] atherogenic alterations [36] and micro and macrovascular diabetic complications [37].

The present study was designed to assess the protective effects of: 1) a garlic extract; and 2) a combination of $\alpha$-tocopherol and $\mathrm{Mg}$ on kidney and brain damages due to an alloxan-induced diabetes in rats. Measured biological parameters were: plasma creatinine, urea, uric acid and cortisol levels, proteinuria and urinary volume. Lipids peroxidation level and antioxidant enzymes (SOD, GPX, CAT) activities were determined in kidney and brain. A phytochemical study of the garlic extract was carried out to identify some antioxidative substances.

\section{Materials and Methods}

\subsection{Preparation of the Garlic Extract}

Aqueous garlic extract was prepared by using a protocol published by Thomson et al. [5] and slightly modified in our laboratory. Briefly, $30 \mathrm{~g}$ of peeled garlic was cut into small pieces and homogenized in $70 \mathrm{ml}$ of ice-cold saline $(300 \mathrm{mM} \mathrm{NaCl})$. The homogenization was carried out for $15 \mathrm{~min}$ in a blender at high speed using $30 \mathrm{sec}$ bursts spaced by cooling intervals to avoid excessive heating of the mixture. The homogenate was filtered 3 times through cheesecloth and the filtrate was centrifuged at $(2000 \times \mathrm{g})$ for $10 \mathrm{~min}$. The resulting clear supernatant was diluted to $100 \mathrm{ml}$ with saline. The aqueous extract of garlic was stored in small aliquots at $-20^{\circ} \mathrm{C}$ until use.

\subsection{Experimental Induction of Diabetes}

Rats were i.p. injected with a freshly prepared solution of alloxan monohydrate in saline $(300 \mathrm{mM} \mathrm{NaCl})$ at a dose of $120 \mathrm{mg} / \mathrm{kg}$ body weight as proposed by Al-Shamaony et al. [38]. Since alloxan injection can provoke fatal hypoglycaemia as a result of reactive massive release of insulin, rats were also given orally $5-10 \mathrm{ml}$ of a $20 \%$ glucose solution after $6 \mathrm{~h}$. Rats were then kept for the next $24 \mathrm{~h}$ on a $5 \%$ glucose solution as beverage to prevent too severe hypoglycaemia [39]. After 2 weeks, rats displaying glycosuria and hyperglycaemia (over $2 \mathrm{~g} / \mathrm{l}$ ) were chosen for the experiments.

\subsection{Experimental Design}

3-month-old Wistar male rats, about $160 \mathrm{~g}$ body weight, fed on $15 \%$ proteins food pellets (SICO, Sfax, Tunisia), were kept in a breeding farm, at $22^{\circ} \mathrm{C}$, with a stable hygrometry, under constant photoperiod.

The rats were divided into 4 batches: (C) was control group, (D) was alloxan-diabetic rats, (D + G) was a group of alloxan-diabetic rats injected with garlic extract $(1 \mathrm{ml}$ of the extract corresponding to $300 \mathrm{mg}$ fresh garlic $/ \mathrm{kg}$ ), and $(\mathrm{D}+\mathrm{EMg})$ was a group of alloxan-diabetic rats injected with $\alpha$-tocopherol together with $\mathrm{MgCl}_{2}$ (100 and $200 \mathrm{mg} / \mathrm{kg}$ body weight, respectively) as proposed by Farvid et al. [40] and Aksoy et al. [41]. After 4 weeks, animals from each group were rapidly sacrificed by decapitation in order to minimize the handling stress. The blood serum was obtained by centrifugation $(1500 \times \mathrm{g}$, $15 \mathrm{~min}, 4^{\circ} \mathrm{C}$ ) and the kidney and brain were removed, cleaned of fat and weighed. All these samples were stored at $-80^{\circ} \mathrm{C}$ until use.

\subsection{Biochemical Assays}

Level of lipid peroxidation was measured as thiobarbituric acid reactive substances (TBARS), according to Yagi [42]. For the assay, $125 \mu \mathrm{l}$ of supernatant (S1 of kidney and brain) were mixed with $175 \mu$ of $20 \%$ trichloroacetic acid containing $1 \%$ butyl-hydroxytoluene and centrifuged $\left(1000 \times \mathrm{g}, 10 \mathrm{~min}, 4^{\circ} \mathrm{C}\right)$. Then, $200 \mu \mathrm{l}$ of supernatant (S2) was mixed with $40 \mu \mathrm{l}$ of $\mathrm{HCl}(0.6 \mathrm{M})$ and $160 \mu \mathrm{l}$ of thiobarbituric acid $(0.72 \mathrm{mM})$ and the 
mixture was heated at $80^{\circ} \mathrm{C}$ for $10 \mathrm{~min}$. The absorbance was measured at $530 \mathrm{~nm}$. The amount of TBARS was calculated using an extinction coefficient of 156 $\mathrm{mM}^{-1} \cdot \mathrm{cm}^{-1}$ and expressed in nmoles/mg protein.

Catalase (CAT) activity was measured according to Aebi [43]. The reaction mixture $(1 \mathrm{ml})$ contained 100 $\mathrm{mM}$ phosphate buffer $(\mathrm{pH}=7), 100 \mathrm{mM} \mathrm{H}_{2} \mathrm{O}_{2}$ and $20 \mu \mathrm{l}$ (about $1-1.5 \mathrm{mg}$ of protein) of kidney or brain homogenate. $\mathrm{H}_{2} \mathrm{O}_{2}$ decomposition was followed at $25^{\circ} \mathrm{C}$ by measuring the decrease in absorbance at $240 \mathrm{~nm}$ for 1 min. Enzyme activity was calculated using an extinction coefficient of $0.043 \mathrm{mM}^{-1} \cdot \mathrm{cm}^{-1}$ and expressed in international units (I.U.), i.e., in $\mu \mathrm{M} \mathrm{H}_{2} \mathrm{O}_{2}$ destroyed min/mg protein.

The total (Cu-Zn and Mn) superoxide-dismutase (SOD) activity was determined by measuring its ability to inhibit the photoreduction of nitroblue tetrazolium (NBT) $[44,45]$. One unit of SOD represents the amount inhibiting the photoreduction of NBT by $50 \%$. The activity was expressed as units $/ \mathrm{mg}$ protein, at $25^{\circ} \mathrm{C}$.

Glutathione-peroxidase (GPX) activity was assayed according to the method of Flohe and Gunzler [46]. The activity at $25^{\circ} \mathrm{C}$ was expressed as $\mu$ moles of GSH oxi$\mathrm{dized} / \mathrm{min} / \mathrm{g}$ protein.

Protein content in tissue extracts was determined according to the Lowry's method. [47] using bovine serum albumin as standard.

The level of creatinine, urea, acid uric and cortisol in serum were determined by kit method (Spinreact).

\subsection{Assay of Free Radical-Scavenging Activity on DPPH}

The free radical-scavenging activity of garlic was evaluated using the stable radical DPPH, according to the method of Grzegorczyk et al. [48]. An aqueous solution of garlic $(1 \mathrm{ml})$ at various concentrations $(50-400 \mu \mathrm{g} / \mathrm{ml})$ was added to $1 \mathrm{ml}$ of a $0.1 \mathrm{mM}$ methanolic solution of $\mathrm{DPPH}$ and allowed to stand for $30 \mathrm{~min}$ at $27^{\circ} \mathrm{C}$. The absorbance was then measured at $517 \mathrm{~nm}$.

DPPH radical-scavenging activity (RSA), expressed as percent was calculated using the following formula: RSA $\%=A_{D P P H}-\left(A_{\text {sample }}-A_{\text {control }}\right) \times 100 / A_{D P P H}$.

\subsection{Extraction of Garlic Phenolic Acids and Flavonoids}

$1 \mathrm{~g}$ of garlic was mixed with $10 \mathrm{ml}$ of extraction solution (methanol 80\%) agitated for $10 \mathrm{~min}$ and then centrifuged at $12,000 \times \mathrm{g}$ for $5 \mathrm{~min}$. An aliquot of supernatant $(0.5 \mathrm{ml})$ was added to $0.5 \mathrm{ml}$ of acetone and agitated. The homogenate was then centrifuged $(12,000 \times \mathrm{g}$ for $5 \mathrm{~min})$. A Speed Vac device was used to dry the homogenate which was then used for HPLC analysis of phenolic acids and flavonoids.

\subsection{HPLC Analysis Conditions}

Analyses by liquid chromatography were performed using a Varian Prostar HPL equipped with a ternary pump (model Prostar 230) and a Prostar 330 diode array detector. The HPLC separation of the active compounds was carried out on C-18 reverse phase HPLC column (Varian, $150 \mathrm{~mm} \times 4.6 \mathrm{~mm}$, particle size $5 \mu \mathrm{m}$ ) on an elution gradient at $25^{\circ} \mathrm{C}$. Eluent A was pure methanol and eluent $\mathrm{B}$ was $0.05 \%$ acetic acid aqueous solution. Gradient conditions was initial $=35 \% \mathrm{~A}$ and $65 \% \mathrm{~B} ; 30 \mathrm{~min}=50 \% \mathrm{~A}$ and $50 \% \mathrm{~B} ; 40 \mathrm{~min}=90 \% \mathrm{~A}$ and $10 \% \mathrm{~B}$. The flow rate was $1 \mathrm{ml} / \mathrm{min}$ and the injection volume was $20 \mu \mathrm{l}$. The identifications were performed at $230 \mathrm{~nm}$ for phenolic acids and at $365 \mathrm{~nm}$ for flavonoids.

\subsection{Statistical Analysis}

Two independent experiments, each carried out on 24 rats, were performed. Data were expressed as mean \pm standard deviation (SD). Statistical significance was assessed by Student's t-test. $\mathrm{p}<0.05$ was considered statistically significant.

\section{Results}

\subsection{Body Weight, Urinary Volume and Proteinuria Level}

As seen on Figure 1, body weight of diabetic rats was reduced whereas it increased throughout the 4-weeks experimental period in control animals. Treatments of diabetic rats with garlic extract or $\alpha$-tocopherol $+\mathrm{Mg}$ were somewhat beneficial since they elicited some weight gain.

Both urine output rate and proteinuria were significantly increased (by $+116 \%$ and $+317 \%$ respectively) in alloxan-diabetics rats as compared to controls. In diabetic animals treated with garlic extract or $\alpha$-tocopherol $+\mathrm{Mg}$,

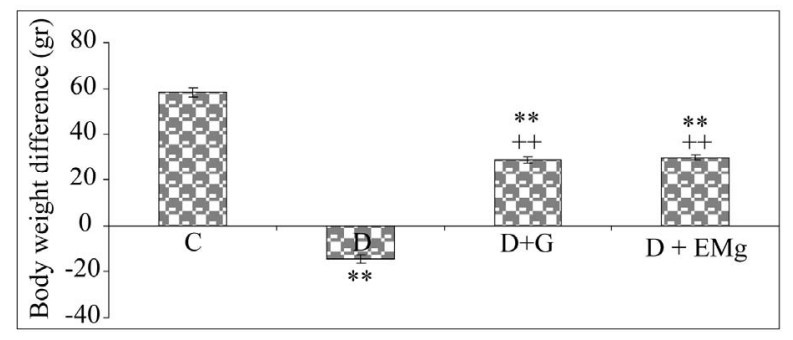

Figure 1. Comparison of body weights after 4 weeks in control, diabetic and treated diabetic rats. The mean weight of all animals was $160 \mathrm{~g}$ when starting the experiments. $\mathrm{C}$ : Control (normal) rats; D: Diabetics rats; D + G: Diabetic rats treated with garlic extract; D + EMg: Diabetic rats treated with $\alpha$-tocopherol + Mg. Values are the mean of 6 measurements $\pm \mathrm{SD}$. "** Significant difference as compared to control rats $(C)(p \leq 0.01) ;{ }^{++}$Significant difference between treated diabetic rats $(D+G ; D+E M g)$ and diabetic rats (D). 
these parameters were brought back to almost normal values after 4 weeks (Figure 2).

\subsection{Serum Markers of Kidney Damages and Cortisol Level}

Plasma creatinine, urea and cortisol levels were significantly increased by $(+69 \%,+90 \%$ and $+43 \%$, respectively) and plasma uric acid level was decreased (-24\%) in diabetics rats as compared to controls. When diabetic rats were treated with garlic extract or with $\alpha$-tocopherol $+\mathrm{Mg}$, a significant normalization of these parameters was observed, as compared to untreated diabetic rats (Figures 3-5).

\subsection{Oxidative Damages}

As shown in Tables $\mathbf{1}$ and 2, TBARS levels, markers of

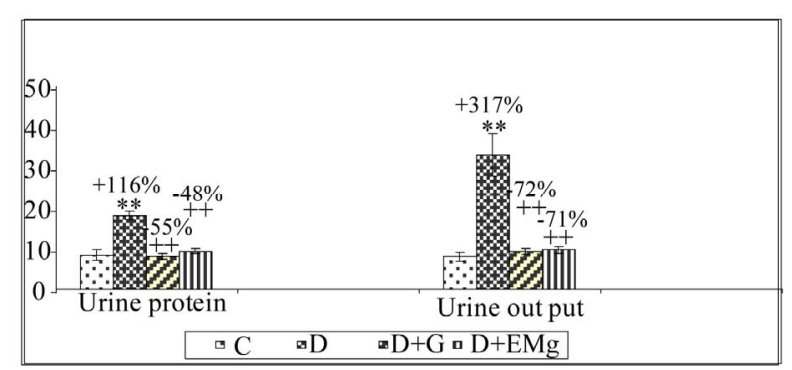

Figure 2. Urine protein $(\mathrm{mg} / 24 \mathrm{~h})$ and urine output $(\mathrm{ml} /$ day) levels after 4 weeks in control, diabetic and treated diabetic rats. C: Control (normal) rats; D: Diabetics rats; D + G: Diabetic rats treated with Garlic extract; D + EMg: Diabetic rats treated with $\alpha$-tocopherol + Mg. Values are the mean of 6 measurements \pm SD. ${ }^{* * *}$ Significant difference as compared to control rats $(C)(p \leq 0.01) ;{ }^{++}$Significant difference between treated diabetic rats $(D+G ; D+E M g)$ and diabetic rats (D).

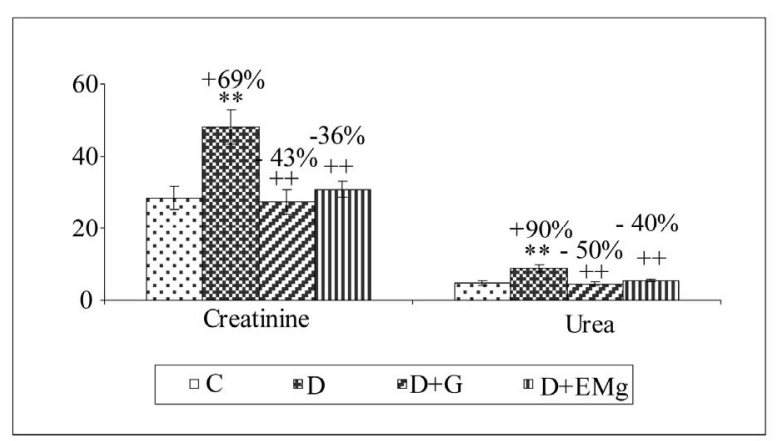

Figure 3. Serum creatinine $(\mu \mathrm{mol} / \mathrm{l})$ and urea $(\mathrm{mmol} / \mathrm{l})$ levels after 4 weeks in control, diabetic and treated diabetic rats. C: Control (normal) rats; D: Diabetics rats; D + G: Diabetic rats treated with garlic extract; D + EMg: Diabetic rats treated with $\alpha$-tocopherol + Mg. Values are the mean of 6 measurements \pm SD. ${ }^{* * *}$ Significant difference as compared to control rats $(C)(p \leq 0.01)$; ${ }^{++}$Significant difference between treated diabetic rats $(D+G ; D+E M g)$ and diabetic rats (D).

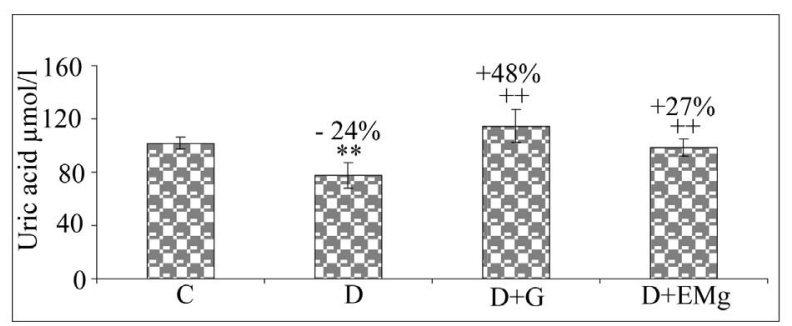

Figure 4. Uric acid ( $\mu \mathrm{mol} / \mathrm{l})$ level after 4 weeks in control, diabetic and treated diabetic rats. C: Control (normal) rats; D: Diabetics rats; D + G: Diabetic rats treated with Garlic extract; D + EMg: Diabetic rats treated with $\alpha$-tocopherol + Mg. Values are the mean of 6 measurements \pm SD. ${ }^{* *}$ Significant difference as compared to control rats $(C)(p \leq 0.01)$; ${ }^{++}$Significant difference between treated diabetic rats $(\mathrm{D}+\mathrm{G}$; D + EMg) and diabetic rats (D).

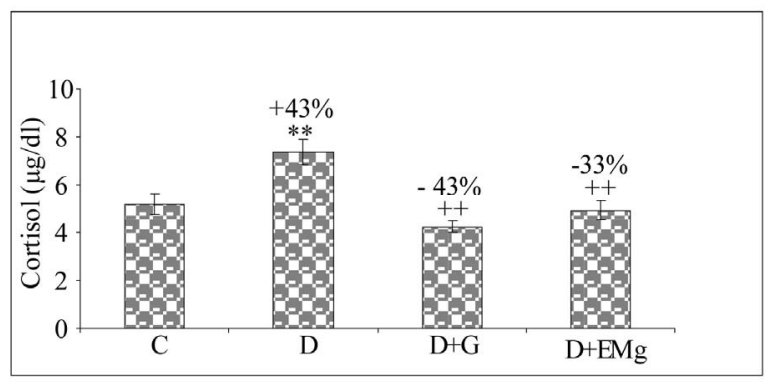

Figure 5. Cortisol $(\mu \mathrm{g} / \mathrm{dl})$ level after 4 weeks in control, diabetic and treated diabetic rats. C: Control (normal) rats; $D$ : Diabetics rats; D + G: Diabetic rats treated with Garlic extract; D + EMg: Diabetic rats treated with $\alpha$-tocopherol + Mg. Values are the mean of 6 measurements \pm SD. ${ }^{* *}$ Significant difference as compared to control rats (C) $(p \leq$ $0.01) ;{ }^{++}$Significant difference between treated diabetic rats (D + G; D + EMg) and diabetic rats (D).

lipids peroxidation, were increased in kidney and brain of diabetic rats as compared to controls (by $+90 \%$ and $+87 \%$, respectively). Administration of garlic extract or $\alpha$-tocopherol $+\mathrm{Mg}$ significantly reduced TBARS levels in kidney and brain of the diabetic rats.

\subsection{Activities of Antioxidant Enzymes}

Activities of SOD, CAT and GPX were found to be respectively reduced by $-42 \%,-55 \%,-70 \%$ in kidney and by $-41 \%,-45 \%,-40 \%$ in brain of alloxan-diabetic rats, as compared to control values (Tables 1 and 2). These changes, revealing a weaker defense against an oxidative stress, were largely corrected in animals treated with garlic extract or $\alpha$-tocopherol $+\mathrm{Mg}$.

\section{Discussion}

Diabetes is a complex metabolic disorder, involving characteristic alterations of glucose metabolism. In diabetic patients, insulin is not produced or is insufficiently produced (diabetes type 1) or peripheral receptors to in- 
Table 1. TBARS (nmol/mg protein) levels and enzyme activities of SOD (U/mg protein), GPX (U/mg protein) and CAT (U/mg protein) in kidney after 4 weeks of treatment in control, diabetic and treated diabetic rats.

\begin{tabular}{ccccc}
\hline & TBARS & SOD & GPX & CAT \\
\hline C & $0.4 \pm 0.05$ & $27.6 \pm 1.42$ & $0.67 \pm 0.5$ & $35.6 \pm 4.19$ \\
D & $0.74 \pm 0.08^{* *}$ & $15.96 \pm 1^{* *}$ & $0.2 \pm 0.08^{* *}$ & $16.16 \pm 1.16^{* *}$ \\
D + G & $0.36 \pm 0.06^{++}$ & $23.72 \pm 2.9^{++}$ & $0.7 \pm 0.1^{++}$ & $32.5 \pm 3.93^{++}$ \\
D + EMg & $0.38 \pm 0.04^{++}$ & $27 \pm 3.3^{++}$ & $0.76 \pm 0.103^{++}$ & $37.5 \pm 3.45^{++}$ \\
\hline
\end{tabular}

C: Control (normal) rats; D: Diabetics rats; D + G: Diabetic rats treated with garlic extract; D + EMg: Diabetic rats treated with $\alpha$-tocopherol $+\mathrm{Mg}$. Values are the mean of 6 measurements $\pm \mathrm{SD}$. ${ }^{* *}$ Significant difference as compared to control rats $(\mathrm{C})(\mathrm{p} \leq 0.01) ;{ }^{++}$Significant difference between treated diabetic rats $(\mathrm{D}+\mathrm{G} ; \mathrm{D}+\mathrm{EMg})$ and diabetic rats $(\mathrm{D})$.

Table 2. TBARS (nmol/mg protein) levels and enzyme activities of SOD (U/mg protein), GPX (U/mg protein) and CAT (U/mg protein) in brain after 4 weeks of treatment in control, diabetic and treated diabetic rats.

\begin{tabular}{ccccc}
\hline & TBARS & SOD & GPX & CAT \\
\hline C & $0.65 \pm 0.08$ & $10 \pm 0.9$ & $7.32 \pm 0.53$ & $21.6 \pm 1.04$ \\
D & $1.25 \pm 0.14^{* *}$ & $5.9 \pm 0,8^{* *}$ & $4.4 \pm 0.5^{* *}$ & $11.95 \pm 0.73^{* *}$ \\
D + G & $0.63 \pm 0.06^{++}$ & $9.8 \pm 1.24^{++}$ & $7.05 \pm 1.1^{++}$ & $23 \pm 2.53^{++}$ \\
D + EMg & $0.7 \pm 0.07^{++}$ & $9,63 \pm 1.4^{++}$ & $7.72 \pm 0.74^{++}$ & $18.63 \pm 1.38^{++}$ \\
\hline
\end{tabular}

C: Control (normal) rats; D: Diabetics rats; D + G: Diabetic rats treated with garlic extract; D + EMg: Diabetic rats treated with $\alpha$-tocopherol $+\mathrm{Mg}$. Values are the mean of 6 measurements $\pm \mathrm{SD}$. ${ }^{* *}$ Significant difference compared to control rats $(\mathrm{C})(\mathrm{p} \leq 0.01) ;{ }^{++}$Significant difference between treated diabetic rats $(\mathrm{D}+\mathrm{G} ; \mathrm{D}+\mathrm{EMg})$ and diabetic rats $(\mathrm{D})$.

sulin lack the normal sensitivity (diabetes type 2), which in both cases causes hyperglycaemia and severe alterations of glucose and lipid metabolism. This hyperglycaemia leads to the over-production of free radicals and the non-enzymatic glycation of proteins. These changes are responsible for adverse effects, especially in kidney and brain.

In the present study, alloxan treatment induced in rats 1) a hyperglycaemia; 2) a reduction in glomerular filtration rate objectified by an increased level of plasma creatinine and urea concentrations; and 3) and increase of urine output and proteinuria. According to Keane and Eknoyan [49], proteinuria is a major predictor of glomerular injury and progressive nephropathy. Our findings corroborate the results of previous investigations in streptozotocin-diabetics rats [50].

The weight loss observed in alloxan-diabetic rats can be due both to a reduction of food intake and to the importance of metabolic disorders.

Uric acid level decreased by about $24 \%$ in blood of our diabetics rats. This compound, which is the end product of purine catabolism, also exerts antioxidative properties and may participate to the defence against an oxi- dative stress by scavenging various ROS [51,52].

Shifts in a variety of biological parameters can be attributed to a general oxidative stress triggered by alloxan treatment and the subsequent hyperglycemia. The increase of plasma cortisol level was also reported by Roy et al. $[53,54]$ and Bitar [55] who suggested that diabetes is associated with stimulation of adrenal cortex. Reduced activities of SOD, CAT and GPX in kidney and brain of diabetic rats also contribute to the worsening of the oxidative stress.

Under our experimental conditions, garlic extract was found to be beneficial in reducing the pathological shifts of all considered parameters. Similar results were reported in alloxan-diabetic rats by El-Demerdash et al. [56] who emphasized the alleviating effect of garlic on renal damage [5] concluded that the most interesting effect of raw garlic in streptozotocin-diabetic rats was to lower proteinuria and urine output levels. Under our experimental conditions, the property of garlic to decrease cortisol level could be related to the reduction of ROS production as suggested by Kasuga et al. [57] when working on the ability of garlic extract to prevent adrenal hypertrophy, hyperglycaemia and elevation of corticosterone in stressed mice.

Garlic effects could be largely due to its antioxidant potential. This explains the ability of garlic extract to reduce TBARS levels in kidney. Imail et al. [58] also observed that garlic extract was able to scavenge the t-butyl hydroperoxide radical and hence prevented lipid peroxidation of liver microsomes.

We found that garlic treatment was able to restore uric acid level in plasma, and the levels of SOD, CAT and GPX activities. This was also reported by Helen et al. [59] who observed that garlic oil supplementation reduced lipids peroxidation and restored activity of antioxidant enzymes what, in turn, increased glutathione levels in cells.

The beneficial effects promoted by garlic could also be attributed to improved antioxidant activity in brain, which potentially could result in reduction in membrane lipid peroxidation. Being a large consumer of oxygen, containing high rate of polyunsaturated fatty acids in membranes and being poor in anti-oxidant defense systems [18], the brain is highly susceptible to oxidative stress. Due to the presence of: 1) allicin and S-allyl cystein sulfoxide which trap the aggressive free radicals [60]; and 2) polyphenols and phytosterols, garlic is a good candidate to counteract the diabetes-associated brain damages [13-18]. The beneficial effects of garlic can be attributed to scavenging free radicals properties as shown by the DPPH test in vitro and by the presence of polyphenols and flavonoids in the garlic extract as shown by the HPLC analysis (Figures 6-8). In fact, phenolic acids and flavonoids were able to liberate a hydrogen proton 
from their hydroxyl group and could scavenge free radicals and prevent kidney and brain from damage induced by hyperglyceamia.

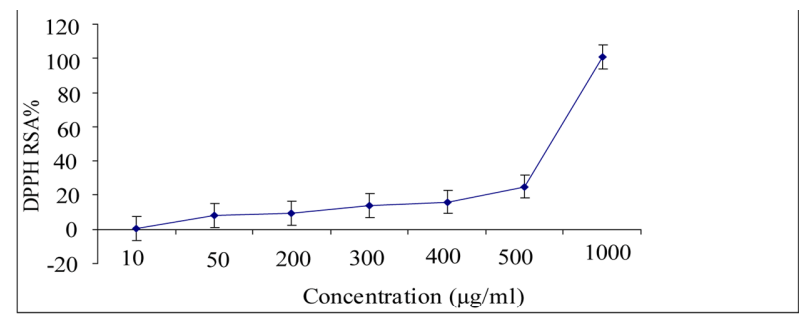

Figure 6. Scavenging activity of garlic extract (at final concentration ranging from 10 to $1000 \mu \mathrm{g} / \mathrm{ml}$ ) upon the DPPH radical. Each value is the mean of 3 separate assays \pm SD. RSA: Radical scavenging activity.

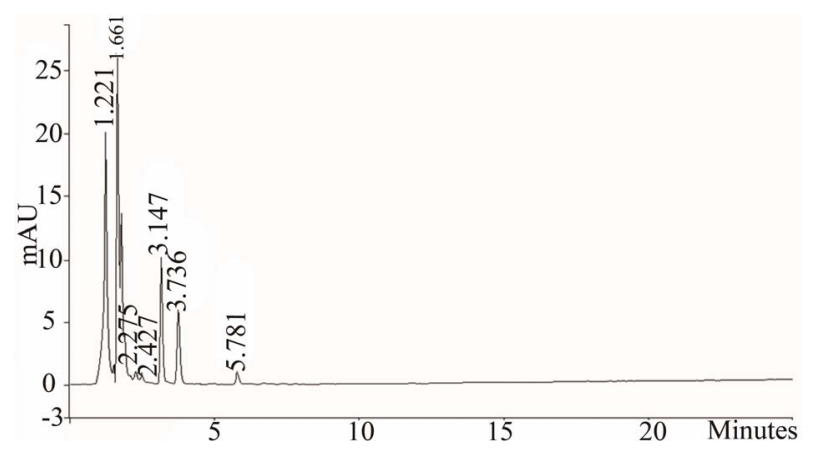

Figure 7. HPLC profile of phenolic acids $(\lambda=230 \mathrm{~nm})$ from garlic aqueous extract. The HPLC analyses were performed using a varian Prostar HPLC equipped with a reverse phase C-18 column (Varian, $150 \mathbf{~ m m} \times \mathbf{4 . 6} \mathbf{~ m m}$, particle size $5 \mu \mathrm{m}$ ) on conjunction with a gradient elution (A, pure methanol; $\mathrm{B}, \mathbf{0 . 0 5} \% \mathrm{CH}_{3} \mathrm{COOH}$ aqueous solution): initial = $35 \% \mathrm{~A}$ and $65 \% \mathrm{~B} ; 30 \mathrm{~min}=50 \% \mathrm{~A}$ and $50 \% \mathrm{~B} ; 40 \mathrm{~min}=$ $90 \% \mathrm{~A}$ and $10 \% \mathrm{~B}$. The flow rate was $0.8 \mathrm{ml} / \mathrm{min}^{-1}$ and the injection volume was $20 \mu \mathrm{L}$ at $25^{\circ} \mathrm{C}$.

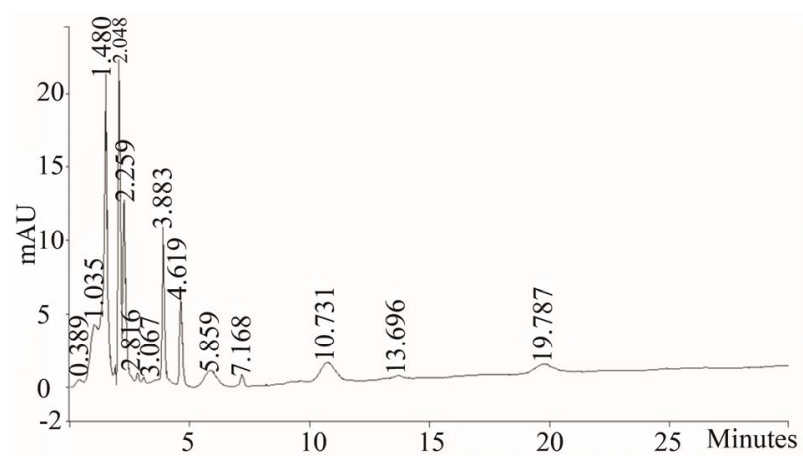

Figure 8. HPLC profile of flavonoids $(\lambda=365 \mathrm{~nm})$ from garlic aqueous extract. The HPLC analyses were performed using a varian Prostar HPLC equipped with a reverse phase C-18 column (Varian, $150 \mathrm{~mm} \times 4.6 \mathrm{~mm}$, particle size $5 \mu \mathrm{m}$ ) on conjunction with a gradient elution (A, pure methanol; $\mathrm{B}, \mathbf{0 . 0 5} \% \mathrm{CH}_{3} \mathrm{COOH}$ aqueous solution): initial = $35 \% \mathrm{~A}$ and $65 \% \mathrm{~B} ; 30 \mathrm{~min}=50 \% \mathrm{~A}$ and $50 \% \mathrm{~B} ; 40 \mathrm{~min}=$ $90 \% \mathrm{~A}$ and $10 \% \mathrm{~B}$. The flow rate was $0.8 \mathrm{ml} / \mathrm{min}^{-1}$ and the injection volume was $20 \mu \mathrm{L}$ at $25^{\circ} \mathrm{C}$.
Under our experimental conditions, not only garlic was found to protect kidney and brain, but the combination of $\alpha$-tocopherol and magnesium was also found to alleviate the diabetes-associated damages. This treatment also reduced blood urea and creatinine levels, proteinuria, TBARS levels in renal and brain tissues and restored body weight, uric acid level and SOD, CAT and GPX activity in kidney and brain. $\alpha$-tocopherol and others antioxidants such as glutathione were shown to improve glucose metabolism and to enhance glucose-induced insulin secretion in aged patients with impaired glucose tolerance. Magnesium was also demonstrated to contribute to the effect of $\alpha$-tocopherol in improving sensitivity to insulin [32].

In conclusion, both garlic and $\alpha$-tocopherol $+\mathrm{Mg}$ treatments appear almost equally able to improve the diabetes-associated pathological conditions in rat brain and kidney.

\section{Acknowledgements}

This research was funded by the Tunisian Ministry higher education, Scientific Research and Technology through the Laboratory of Physiology Faculty of Sciences of Sfax.

\section{REFERENCES}

[1] A. L. McCall, "The Impact of Diabetes on the CNS," Diabetes, Vol. 41, No. 5, 1992, pp. 557-570. doi:10.2337/diabetes.41.5.557

[2] W. H. Gispen and G. J. Biessels, "Cognition and Synaptic Plasticity in Diabetes Mellitus," Trends in Neuroscience, Vol. 23, No. 11, 2000, pp. 542-549. doi:10.1016/S0166-2236(00)01656-8

[3] J. H. Hong, M. R. Kim Park, O. G. Kwag, K. B. Lee and S. J. Rhee, "Effects of Vitamin E on Oxidative Stress and Membrane Fluidity in Brain of Streptozotocin-Induced Diabetics Rats," Clinica Chimica Acta, Vol. 340, No. 1-2, 2004, pp. 107-115. doi:10.1016/j.cccn.2003.10.003

[4] H. Vural, T. Sabuncu, S. O. Arslan and N. Aksoy, "Melatonin Inhibits Lipid Peroxidation and Stimulates the Antioxidant Enzymes in Colon of Methylazoxymethanol Treated Rats," Clinical Chemistry and Laboratory Medicine, Vol. 8, 2000, pp. 1051-1053.

[5] M. Thomson, Z. M. Al Amin, K. K. Al-Qattan, L. H. Shaban and Ali Muslim, "Anti-Diabetic and Hypolipidaemic Properties of Garlic (Allium Sativum) in Streptozotocin-Induced Diabetic Rats," International Journal of Diabetes \& Metabolism, Vol. 15, 2007, pp. 108-115.

[6] D. Dreher and A. F. Junod, "Role of Oxygen Free Radicals in Cancer Development," European Journal of Cancer, Vol. 32A, No. 1, 1996, pp. 30-38. doi:10.1016/0959-8049(95)00531-5

[7] H. D. Hammers, S. Martin, K. Fedesrlin, K. Geisen and M. Brownlle, "Aminoguanidine Treatment Inhibit the Development of Complications in Diabetes," Diabetes, 
Vol. 40, 1991, pp. 405-412.

[8] G. J. Biesells, A. C. Kapella, B. Bravenboer, D. W. Erkelens and W. H. Gispen, "Cerebral Function in Diabetes Mellitus," Diabetologia, Vol. 37, No. 7, 1994, pp. 643650. doi:10.1007/BF00417687

[9] G. Baydas, H. Canatan and A. Turkoglu, "Comparative Analyses of the Protective Effects of Melatonin and Vitamin E on Streptozotocin-Induced Diabetes Mellitus," Journal of Pineal Research, Vol. 32, No. 4, 2002, pp. 225230. doi:10.1034/j.1600-079X.2002.01856.x

[10] R. M. Couch, "Dissociation of Cortisol and Adrenal Androgen Secretion in Poorly Controlled Insulin-Dependent Diabetes Mellitus," Acta Endocrinologica, Vol. 127, No. 2, 1992, pp. 115-117.

[11] Y. B. Lambardo and A. G. Chicco, "Effects of Dietary Polyunsaturated n-3 Fatty Acids on Dyslipidemia and Insulin Resistance in Rodents and Humans. A Review," The Journal of Nutritional Biochemestry, Vol. 17, No. 1, 2006, pp. 1-13. doi:10.1016/i.jnutbio.2005.08.002

[12] J. K. Grover, S. Yadav and V. Vats, "Medicinal Plants of India with Anti-Diabetes Potential," Journal of Ethnopharmacology, Vol. 81, No. 1, 2002, pp. 81-100. doi:10.1016/S0378-8741(02)00059-4

[13] K. T. Augusti and C. G. Sheela, "Antiperoxide Effect of S-Allyl Cysteine Sulfoxide, a Insulin Secretagogue, in Diabetic Rats," Experientia, Vol. 52, No. 2, 1996, pp. 115-120. doi:10.1007/BF01923354

[14] M. Ali and M. Thomson, "Consumption of a Garlic Clove a Day Could Be Beneficial in Preventing Thrombosis," Prostaglandins Leukot Essent Fatty Acids, Vol. 53, No. 3, 1995, pp. 211-212. doi:10.1016/0952-3278(95)90118-3

[15] T. Bordia, N. Mohammed, M. Thomson and M. Ali, "An Evaluation of Garlic and Onion as Antithrombotic Agents," Prostaglandins, Leukotrienes and Essential Fatty Acids, Vol. 54, No. 3, 1996, pp. 183-186. doi:10.1016/S0952-3278(96)90014-9

[16] M. Thomson, T. Mustafa and M. Ali, "Thromboxane-B2 Levels in Serum of Rabbits Receiving a Single Intravenous Dose of Aqueous Extract of Garlic and Onion," Prostaglandins, Leukotrienes and Essential Fatty Acids, Vol. 63, No. 4, 2000, pp. 217-221. doi:10.1054/plef.2000.0212

[17] M. M. Anwar and A. R. Meki, "Oxidative Stress in Streptozotocin-Induced Diabetic Rats: Effects of Garlic Oil and Melatonin," Comparative Biochemistry and Physiology Part A: Molecular \& Integrative Physiology, Vol. 135, No. 4, 2003, pp. 539-547. doi:10.1016/S1095-6433(03)00114-4

[18] K. Rahman, "Garlic and Aging: New Insights into an Old Remedy," Ageing Research Reviews, Vol. 2, No. 1, 2003, pp. 39-56. doi:10.1016/S1568-1637(02)00049-1

[19] M. Ali, K. K. Al-Qattan, F. Al-Enezi, R. M. Khanafer and T. Mustafa, "Effect of Allicin from Garlic Powder on Serum Lipids and Blood Pressure in Rats Fed with a High Cholesterol Diet," Prostaglandins, Leukotrienes and Essential Fatty Acids, Vol. 62, No. 4, 2000, pp. 253-259. doi:10.1054/plef.2000.0152

[20] A. Eidi, M. Eidi and E. Esmaeili, "Antidiabetic Effect of Garlic (Allium sativum L.) in Normal and Streptozotocin-
Induced Diabetic Rats," Phytomedicine, Vol. 13, No. 9-10, 2006, pp. 624-629. doi:10.1016/j.phymed.2005.09.010

[21] B. B. Whitemore and A. S. Naidu, "Thiosulfinates," In: A. S. Naidu, Ed., Natural Food Antimicrobial Systems, CRC Press, Boca Raton, 2000, pp. 265-380. doi:10.1201/9781420039368.ch13

[22] J. T. Pinto and R. S. Rivlin, "Antiproliferative Effects of Allium Derivatives from Garlic," Journal of Nutrition, Vol. 131, No. 3S, 2001, pp. 1058S-1060S.

[23] S. K. Banerjee and S. K. Maulik, "Effect of Garlic on Cardiovascular Disorders: A Review," Nutrition Journal, 2002, Vol. 1, p. 4. doi:10.1186/1475-2891-1-4

[24] T. Moriguchi, K. Takashina, P. J. Chu, H. Saito and N. Nishiyama, "Prolongation of Life Span and Improved Learning in the Senescence Accelerated Mouse Produced by Aged Garlic Extract," Biological \& Pharmaceutical Bulletin, Vol. 17, No. 12, 1994, pp. 1589-1594.

[25] T. Moriguchi, H. Saito and N. Nishiyama, "Anti-Aging Effect of Aged a Garlic Extract in the Inbred Brain Atrophy Mouse Model," Clinical and Experimental Pharmacology and Physiology, Vol. 24, No. 3-4, 1997, pp. 235242. doi:10.1111/j.1440-1681.1997.tb01813.x

[26] O. I. Aruoma, J. P. E. Spencer, D. Warren, P. Jenner, J. Butler and B. Haliwell, "Characterisation of Food Antioxidants, Illustrated Using Commercial Garlic and Ginger Preparations," Food Chemistry, Vol. 60, No. 2, 1997, pp. 149-156. doi:10.1016/S0308-8146(95)00254-5

[27] F. Sun, K. Iwaguchi, R. Shudo, Y. Nagaki, K. Tanaka, K. Ikeda, et al., "Change in Tissue Concentrations of Lipid Hydroperoxides, Vitamin C and Vitamin E in Rats with Streptozotocin-Induced Diabetes," Clinical Science, Vol. 96, 1999, pp. 185-190. doi:10.1042/CS19980189

[28] H. Murase, J. H. Moon, R. Yamauchi, K. Kato, T. Yoshikawa and J. Terao, "Antioxidant Activity of a Novel Vitamin E Derivative, 2-(Alpha-D-Glucopyranosyl) Methyl2,5,7,8,-Tetramethylchroman-6-ol," Free Radical Biology and Medicine, Vol. 24, No. 2, 1998, pp. 217-225. doi:10.1016/S0891-5849(97)00221-9

[29] J. T. Salonen, K. Nyyssonen, T. P. Tuomainen, P. H. Maenpaa, H. Korpela, G. A. Kaplan, et al., "Increased Risk of Noninsulin Dependent Diabetes Mellitus at Low Plasma Vitamin E Concentrations: A Four Year Follow-Up Study in Men," British Medical Journal, Vol. 311, 1995, pp. 1124-1127. doi:10.1136/bmj.311.7013.1124

[30] R. Andrew, P. Skyrme-Jones, R. C. O’Brien, K. L. Berry and I. T. Meredith, "Vitamin Supplementation Improves Endothelial Function in Type 1 Diabetes Mellitus. A Randomized Placebo-Controlled Study," Journal of the American College of Cardiology, Vol. 36, No. 1, 2000, pp. 94 102. doi:10.1016/S0735-1097(00)00720-8

[31] N. E. Saris, E. Mervaala, H. Karppanen, J. A. Khawaja and A. Lewenstam, "Magnesium: An Secretagogue, in Diabetic Rats," Experientia, Vol. 52, 2000, pp. 115-120.

[32] M. Barbagallo, L. J. Dominguez, A. Galioto, A. Ferlisi, C. Cani, L. Malfa, et al., "Role of Magnesium in Insulin Action, Diabetes and Cardiometabolic Sydrome X," Molecular Aspects of Medicine, Vol. 24, No. 1-3, 2003, pp. 3952. doi:10.1016/S0098-2997(02)00090-0

[33] P. J. Lefebvre, G. Paolisso and A. J. Scheen, "Magnesium 
and Glucose Metabolism," Therapie, Vol. 49, 1994, pp. 17.

[34] W. H. L. Koa, A. R. Folsom, J. F. Nieto, J. P. Mo, R. L. Watson and F. L. Brancati, "Serum and Dietary Magnesium and the Risk for Type 2 Diabetes Mellitus," Archives of Internal Medicine, Vol. 159, No. 18, 1999, pp. 2151-2159. doi:10.1001/archinte.159.18.2151

[35] K. Kisters, C. Spieker, M. Tepel and W. Zidek, "New Data about the Effect of Oral Physiological Magnesium Supplementation on Several Cardiovascular Risk Factors (Lipids and Blood Pressure)," Magnesium Research, Vol. 6, No. 4, 1993, pp. 355-360.

[36] F. Guerrero-Romero and M. Rodriguez-Moran, "Hypomagnesemia Is Linked to Low Serum HDL-Cholesterol Irrespective of Serum Glucose Values," Journal of Diabetes and Its Complications, Vol. 14, No. 5, 2000, pp. 272-276. doi:10.1016/S1056-8727(00)00127-6

[37] J. R. White Jr. and R. K. Campbell, "Magnesium and Diabetes: A Review," The Annals of Pharmacotherapy, Vol. 27, No. 6, 1993, pp. 775-780.

[38] L. Al-Shamaony, S. M. Al-Khazraji and H. A. Twaiji, "Hypoglycaemic Effect of Artemisia herba alba. II. Effect of a Valuable Extract on Some Blood Parameters in Diabetic Animals," Journal of Ethnopharmacology, Vol. 43, No. 3, 1994, pp. 167-171. doi:10.1016/0378-8741(94)90038-8

[39] M. P. Gupta, N. G. Solis, M. Esposito and S. Sanchez, "Hypoglycemic Activity of Neurolaena lobata (L) R. Br.," Journal of Ethnopharmacology, Vol. 10, No. 3, 1984, pp. 323-327. doi:10.1016/0378-8741(84)90020-5

[40] M. S. Farvid, F. Siassi, M. Jalali, M. Hosseini and N. Saadat, "The Impact of Vitamin and/or Mineral Supplementation on Lipid Profiles in Type 2 Diabetes," Diabetes Research and Clinical Practice, Vol. 65, No. 1, 2004, pp. 21-28. doi:10.1016/j.diabres.2003.11.009

[41] N. Aksoy, H. Vural, T. Sabuncu, O. Arslan and S. Aksoy, "Beneficial Effects of Vitamins C and E against Oxidative Stress in Diabetic Rats," Nutrition Research, Vol. 25, No. 6, 2005, pp. 625-630. doi:10.1016/j.nutres.2005.05.005

[42] K. Yagi, "A Simple Fluorometric Assay for Lipoperoxide in Blood Plasma," Biochemical Medicine, Vol. 15, No. 2, 1976, pp. 212-216. doi:10.1016/0006-2944(76)90049-1

[43] H. Aebi, "Catalase in Vitro," Methods in Enzymology, Vol. 105, 1984, pp. 121-126. doi:10.1016/S0076-6879(84)05016-3

[44] Y. Sun, L. W. Oberley and Y. Li, "A Simple Method for Clinical Assay of Superoxide Dismutase," Clinical Chemistry, Vol. 34, No. 3, 1988, pp. 497-500.

[45] I. Durak, Z. Yurtarslanl, O. Canbolat and O. Akyol, "A Methodological Approach to Superoxide Dismutase (SOD) Activity Assay Based on Inhibition of Nitroblue Tetazolium (NBT) Reduction," Clinica Chimica Acta, Vol. 214, No. 1, 1993, pp. 103-104. doi:10.1016/0009-8981(93)90307-P

[46] L. Flohe and W. A. Gunzler, "Assays of Glutathione Peroxidase," Methods in Enzymology, Vol. 105, No. 1, 1984, pp. 114-121. doi:10.1016/S0076-6879(84)05015-1
[47] O. H. Lowry, N. J. Rosebrough, A. L. Farr and R. J. Randall, "Protein Measurement with the Folin Phenol Reagent," The Journal of Biological Chemistry, Vol. 193, 1951, pp. 265-275.

[48] I. Grzegorczyk, A. Matkowski and H. Wysokinska, “Antioxidant Activity of Extracts from in Vitro Cultures of Salvia officinalis L.," Food Chemistry, Vol. 104, No. 2, 2007, pp. 536-541. doi:10.1016/j.foodchem.2006.12.003

[49] W. F. Kaene and G. Eknoyan, "Proteinuria, Albuminuria, Risk, Assessment, Detection, Elimination (PARADE): A Position Paper of the National Kidney Foundation," American Journal of Kidney Diseases, Vol. 33, No. 5, 1999, pp. 1004-1010. doi:10.1016/S0272-6386(99)70442-7

[50] K. A. Greive, T. M. Osicka, L. M. Russo and W. D. Comper, "Nephrotic-Like Proteinuria in Experimental Diabetes," American Journal of Nephrology, Vol. 23, No. 1, 2003, pp. 38-46. doi:10.1159/000066297

[51] B. N. Ames, R. Cathcart, E. Schwiers, et al., "Uric Acid Provides an Antioxidant Defense in Humans against Oxidant and Radical-Caused Aging and Cancer: A Hypothesis," Proceedings of the National Academy of Sciences of the United States of America, Vol. 78, No. 11, 1981, pp. 6858-6862. doi:10.1073/pnas.78.11.6858

[52] F. Regoli and G. W. Winste, "Quantification of Total Oxidant Scavenging Capacity of Antioxidants for Peroxynitrite Peroxyl Radicals and Hydroxyl Radicals," Toxicology and Applied Pharmacology, Vol. 156, No. 2, 1999, pp. 96-105. doi:10.1006/taap.1999.8637

[53] M. Roy, B. Collier and A. Roy, "Hypothalamic-PituitaryAdrenal Axis Dysregulation among Diabetic Outpatients," Psychiatry Research, Vol. 31, No. 1, 1990, pp. 31-37.

[54] M. S. Roy, A. Roy, W. T. Gallucci, B. Gollier, K. Young, T. Kamilaris and G. P. Chrousos, "The Ovine Corticotrophin-Releasing Hormone Stimulation Test in Type I Diabetic Patients and Controls: Suggestion of Mild Chronic Hypercortisolism," Metabolism, Vol. 42, No. 6, 1993, pp. 696-700. doi:10.1016/0026-0495(93)90235-G

[55] M. S. Bitar, "Glucocorticoid Dynamics and Impaired Wound Healing in Diabetes Mellitus," The American Journal of Pathology, Vol. 152, No. 2, 1998, pp. 547-553.

[56] F. M. El-Demerdash, M. I. Yousef and N. I. El-Naga, "Biochemical Study on the Hypoglycemic Effects of Onion and Garlic in Alloxan-Induced Diabetics Rats," Food and Chemical Toxicology, Vol. 43, No. 1, 2005, pp. 5763. doi:10.1016/j.fet.2004.08.012

[57] S. Kasuga, M. Ushijima, N. Morihara, et al., "Effect of Aged Garlic Extract (AGE) on Hyperglycemia Induced by Immobilisation Stress in Mice," Nippon Yakurigaku Zasshi, Vol. 114, No. 3, 1999, pp. 191-197. doi:10.1254/fpj.114.191

[58] J. Imai, N. Ide, S. Nagae, T. Moriguchi and Y. Itakura, "Antioxidant and Radical Scavenging Effects of Aged Garlic Extract and Its Constituents," Planta Medica, Vol. 60, No. 5, 1994, pp. 417-420. doi:10.1055/s-2006-959522

[59] A. Helen, C. R. Rajasree, K. Krishnakumar, K. T. Augusti and P. L. Vijayammal, "Antioxidant Role of Oils Isolated from Garlic (Allium sativum Linn) and Onion 
(Allium cepa Linn) on Nicotine-Induced Lipid Peroxidation," Veterinary \& Human Toxicology, Vol. 41, No. 5, 1999, pp. 316-319.

[60] V. Vaidya, K. Ingold and D. Pratt, "Garlic: Source of the
Ultimate Antioxidants: Sulfenic Acids," Angewandte Chemie, Vol. 121, No. 1, 2009, pp. 163-166.

doi:10.1002/ange. 200804560 